\title{
A study on relationship between earnings before tax, interest and operational cash flows with stockholders' equity
}

\author{
Mohammad Reza karimi Torghabeh ${ }^{\mathrm{a}}$, Hossein Parsian ${ }^{\mathrm{b}}$ and Amir Shams Kolookhi ${ }^{\mathrm{b}^{*}}$
}

${ }^{a}$ Department of Accounting, Torbat-e-Jam Branch, Islamic Azad University, Torbat-e-Jam, Iran

${ }^{b}$ Young Researchers and Elite Club, Torbat-e-Jam Branch, Islamic Azad University, Torbat-e-Jam, Iran

\section{CH R O I C L E A B S T R A C T}

Article history:

Received January 20, 2014

Accepted 5 July 2014

Available online

July 122014

Keywords:

Information asymmetry

Accruals

Operational cash flow

Stockholders' return

\begin{abstract}
One of the primary economic issues is associated with optimum resource allocation in profitable investments with reasonable risk. For this purpose, performance measurement's criteria are needed some of which emphasize cash flow variables and some others focus on information content of accounting profit. On this basis, this study examines the relationship between earnings before tax and interest and operational cash flows with stockholders' return in Tehran Stock Exchange (TSE). In this regard, information asymmetry was also examined. To test hypotheses, multivariable regression and combined data method were used. The results showed that based on the information of 102 companies in stock market from 2004 to 2009 , there was a positive and significant correlation between earnings before interest and tax and stock return in the companies. While, operational cash flow has no significant impact on stock return. Increasing information asymmetry, earnings before interest and tax has a positive and significant correlation with stockholders 'return; but operational cash flow has no significant effect on stockholders' return. In other words, earnings before interest and tax have higher information content than operational cash flow.
\end{abstract}

\section{Introduction}

Optimal resource allocation for high return investments with low or reasonable risk is one of primary economic issues. For information asymmetry, investors need some criteria for evaluating companies' performance to make correct economic decisions. For this purpose, performance evaluation criteria are needed, which deal with variables of cash flow and information content of accounting earnings. Accordingly, this study examines the relationship between earnings before tax and interest and operational cash flows with stockholders' return in Stock Exchange of Tehran. Accounting earnings using accruals are devices for measuring companies' return for the users of financial statements to measure companies' performance evaluating financial status and operations' results for making rational decisions. For example, accounting earnings can be a basis for crediting banks to the

*Corresponding author. Tel: +98-5282210222

E-mail addresses: Shams1122@gmail.com (A. Shams Kolookhi) 
companies or condition of entrance to Tehran Stock Exchange. In Statement 6 of FASB (1985) about financial accounting concepts, using accruals in accounting has been declared obligatory.

Thus, reflecting effects of companies' transactions and events does not mean cash input or output. In other words, in accruals' method, principals such as accomplishment and adoption are used for reflecting incomes, costs, and accounting earnings. Finally, accomplishments of a company depend on its ability in creating cash flows (FASB, 1985). Moreover, operational cash flows are important criteria of performance evaluation for insiders as well as outsiders (e.g. investors and creditors) in the organization. In theoretical framework, financial accounting, which determines the goals of financial reporting pays special attention to cash flows and their predictions. According to Statement 1 of FASB: "one goal of financial reporting is providing information for investors, creditors, and other potential users to assist them at estimations, timing and risk evaluation of future incomes". The perspective of these cash receipts is influencing by the ability of the institute in producing enough cash for fulfilling its obligations in due time and other cash operations such as paying cash stocks' earnings and investors' attitudes toward its abilities that impress stock market (FASB, 1978: Par.37).

In International Accounting Standard, No .7, IASC mentions: "The information of cash flows of a business unit is useful for the users of financial statements in providing cash and the needs of that unit in using them". Economic decisions made by users necessitate evaluating the ability of business unit in creating cash, timing and gaining certainty about them (IASC, 1993). In theoretical concepts of financial reporting, Accounting Standard Board of Iran states: "Making economic decisions by the users of financial statements needs evaluating the ability of business unit for creating cash and certainty about it". Evaluation ability of cash provision is facilitated via focusing on financial status, financial performance, and cash flows of business unit and using them in predicting expected cash flows and measuring financial flexibility (Technical Commite of Accounting, 2012; Par.7). There are differences between accounting earnings and operational cash flows for the effects of the following factors:

Non-cash costs (e.g. depreciation costs) that decrease net profit but not cash amount,

Time difference of income fulfillment and cost tolerance and paying its expenses,

Non-operational profit/loss come from selling fixed assets, bonds, or other investments, considered in profit/loss statements that change net profits. However, in operational activities, cash flows' statements have no effect.

This paper probes the relationship between earnings and operational cash flows with stockholders' return. Then, this relationship is examined in the conditions of information asymmetry to see which one has stronger correlation with stockholders' return.

Gombola and Ketz (1983) studied the relationship between earnings of accruals and operational cash flows. They concluded that cash flows had not had important information compared with accounting earnings. Rayburn (1986) studied the relationship between unexpected components of accruals and cash flows with stock return. The results confirmed that both sections of accounting earnings and cash flows have information content. Wilson (1987) examined the role of information content of earning components towards the values of earning itself through dividing cash and accrual components of earning. The results indicate that earning's accrual components contain incremental information content compared with cash components. Differentiating cash and accruals' components, Wilson (1987) examined the role of information content of earning components compared with the values of earning itself. The results showed that earning's accrual components contained higher information content than its cash components. 
Bowen et al. (1987) studied increasing information content of accruals and cash components. The results showed that information about earnings and cash flows had increasing content towards each other. In addition, the information of cash flows has higher information content than earnings.

In his research, Easton et al. (1992) examined relative information content of earning and cash flows. He found that earning has higher information content compared with cash flows. Considering accounting earnings and cash flows as an index of performance evaluation in his paper, Dechow (1994) indicated that in a firm with less volatility in supplying its required funds, cash flows have better conditions for measuring performance. In his opinion, in short term (e.g. 3 months or a year), firm's earning is more correlated with return and cash flows.

In their research, Hodgson and Stevenson (2000) studied the relationship between earnings and cash flows with stock return affected by firm's size. The results of this study indicated that cash flows provided more additional information for firms with large size than small firms. In addition, smaller firms contain more unstable earning components than large ones. Moreover, non-linear relationship between earnings and cash flows has higher descriptive strength compared with its linear form. Probing the relationship between earning and operational cash flows with stock return in Japan from 1985 to 1993, Charitou et al. (2000) found that when earning has more unstable state, cash flows have more significant role for determining return of the company. Bartov et al. (2001) studied information content of earning and cash flows for evaluating stockholders equity in USA, England, Canada, Germany, and Japan. The results indicated that in USA, England, and Canada, but not in Germany, earning has more significance than cash flows. In other words, national reporting method affects information content of earning and cash flows.

Haw et al. (2001) examined information content of operational cash flows, earning, and accruals in Stock Exchange of China. The results showed that earning contained more information content than operational cash flows; also, incremental information content of discretionary accruals versus nondiscretionary accruals was conformed. Chan et al. (2006) examined the relationship between accruals, difference between earnings and cash flows, and stock return. The results indicated that stock return of firms with high accruals was reduced during next period of financial information reporting.

Probing the relative significance of earning and cash flows in equity evaluation, Subramanyam and Venkatachalam (2007) showed that earning could have better performance in explaining intrinsic realized value compared with cash flows. Rapp (2010) studied the relationship between accounting earnings and cash flows with shareholders' equity in asymmetric conditions of information. He showed that in asymmetric information conditions, accounting earning contains more information content than cash flows. However, through increasing information asymmetry cash flow indices are more relevant in explaining performance of stock market.

\section{Methodology}

This study is correlation. It uses descriptive statistics, Pearson correlation, and regression to analyze data. To test hypotheses, multivariable regression pattern is used with combined data method. Used data in this study are the information of audited financial statements. For this purpose, a main part of information was gathered from Rahavardnovin and Tadbirpardaz software. Other information was gathered from Research Management and Islamic Studies Center of Stock Exchange of Tehran. For statistical tests, E-views software, version 7 was used. Statistical population of this study includes all accepted companies in Tehran Stock Exchange (TSE). Statistical population was selected using removing method. Companies with the following conditions were selected as the sample:

1. They were accepted in TSE until before 2004.

2. Their financial statements were accessible for 2004-2009.

3. They did not have transaction interruption from 2004-2009.

4. Financial period of companies ended at last month of winter. 
For the blurredness of border between operational activities and financial provision of investment, insurance, and holding companies they were removed from the sample. Due to the small sample size, 102 companies and 162 observations for each variable were selected.

\subsection{Hypotheses}

$\mathrm{H}_{1}$. Accounting variables have better performance than variables of cash flows in explaining the performance of companies' stock return (capital market)

$\mathrm{H}_{2}$. Increasing information asymmetry, accounting variables play more significant role in describing companies' stock return performance (capital market) compared with variable of cash flows.

\section{Table 1}

Definitions of variables

\begin{tabular}{llll}
\hline Variables & Definitions of variables & Variables & Definitions of variables \\
\hline $\mathrm{R}_{\mathrm{it}}$ & Percentage of stockholders' return & BETA $_{\mathrm{it}}$ & $\begin{array}{l}\text { Systematic risk resulting from dividing stock return' s covariance \& market return to } \\
\text { variance of market return }\end{array}$ \\
$\mathrm{EAR}_{\mathrm{it}}$ & Earnings before tax and interest & $\mathrm{SIZE}_{\mathrm{it}}$ & Company size calculated by log of total assets \\
$\mathrm{CF}_{\mathrm{it}}$ & Operational cash flow & $\mathrm{MTB}_{\mathrm{it}}$ & Market value/book value of stakeholders \\
$\mathrm{LEV}_{\mathrm{it}}$ & Total debts of company/total assets & $\mathrm{ETP}_{\mathrm{it}}$ & Earnings per share/ stock market price \\
\hline
\end{tabular}

To measure information asymmetry, three dummy variables are used:

$M A C P_{i t}$ : If market value of the company becomes larger than the average market value of annual portfolio, greater than value of market capital, it will take the value of 1, otherwise 0 .

$I N T A N G_{i t}$ : If tangible fixed asset/total assets of the company per year ratio exceed the average of that ratio in annual portfolio, it will take the value of 1 , otherwise 0 .

DOMINATED $_{\text {it }}$ : If floating shares of the company become less than $50 \%$, it will take the value of 1 , otherwise 0 .

\section{Results}

\section{Limer and Hasman tests}

To increase the number of observations and degree of freedom and decrease heterogeneity and collinearity of variables, combined data method was used. First, the likelihood of combining data was used. Next, $F$ test of Limer was utilized whose structure is as follows:

$\mathrm{H}_{0}$ : Intercept parameters are equal in all places (intervals).

$\mathrm{H}_{1}$ : Intercept parameters are not equal in all places (intervals).

Using RRSS from estimations of combined model of OLS and URSS estimations from intergroup regression, $\mathrm{F}$ statistics is introduced as follows:

Equal intercepts in $\mathrm{H}_{0}$ are versus unequal intercepts in $\mathrm{H}_{1}$ (in panel data). Thus if $\mathrm{H}_{0}$ is rejected, panel data method will be accepted. The results of Limer $F$ test for research variables are shown in Table 2.

\section{Table 2}

The results of Limer F test for research variables

\begin{tabular}{lll}
\hline Pattern & F-value & Critical value \\
\hline 1 & 7.76 & $\mathrm{~F}_{101.506}=.076569$ \\
2 & 7.31 & $\mathrm{~F}_{101.500}=.076552$ \\
3 & 7.28 & $\mathrm{~F}_{101.500}=.076552$ \\
4 & 7.15 & $\mathrm{~F}_{101.500}=.076552$ \\
\hline
\end{tabular}

In Table 2, the null hypothesis is to assume intercepts of all periods are equal and based on the critical values stated on Table 2, the null hypothesis for all patterns are rejected. Therefore, we need to use 
Panel data method. To determine fixed and stochastic effects, Hasman Test was utilized. In this test, if accepted, a stochastic pattern is used. The summary of Hasman test results is depicted in Table 3. Due to the significance of all patterns, $\mathrm{H}_{0}$ is rejected. So the pattern of effects is fixed.

Table 3

Hasman test results: selection between fixed and stochastic effects

\begin{tabular}{ccccc}
\hline Research patterns & $\chi 2$ & df & sig & Test result \\
\hline Pattern1 & 6.186 & 2 & .045 & \multirow{2}{*}{ In all patterns, $\mathrm{H}_{0}$ is rejected. } \\
Pattern2 & 70.373 & 8 & .000 & $\mathrm{H}_{0}$ : Coefficient difference is not systematic \\
Pattern3 & 70.225 & 8 & .000 & \\
Pattern4 & 77.209 & 8 & .000 & \\
\hline
\end{tabular}

The analysis of results show that the relationship between dependent and independent variables using panel data can be better represented than using time series data. In other words, in estimating models, intercepts are unequal and there is a significant correlation between error components and explanatory variables. In other words, intercepts are unequal and there is significant difference between intercepts of all explanatory variables. Before hypotheses test, descriptive statistics and Pearson correlation coefficient of variables are shown in Table 4 and 5.

Table 4

Description of descriptive statistics

\begin{tabular}{cccccccccccc}
\hline indices & $\mathrm{R}$ & $\mathrm{CF}$ & EAR & BETA & SIZE & MTB & ETP & LEV & MACP & INTANG & DOMINATED \\
\hline Mean & 102.997 & 207773.6 & 238352.8 & .473 & 11.691 & 2.963 & .146 & .638 & .499 & .500 & .786 \\
Median & 72.910 & 39486.00 & 48080.00 & .540 & 11.657 & 1.843 & .150 & .646 & .000 & 1.000 & 1.000 \\
Max & 919.590 & 10513626 & 8040108 & 3.160 & 13.684 & 115.845 & 2.213 & 1.414 & 1.000 & 1.000 & 1.000 \\
Min & -289.260 & -2413332 & -717929 & -2.310 & 10.588 & -8.304 & -1.660 & .168 & .000 & .000 & .000 \\
sd & 125.460 & 882276.6 & 819674.5 & 1.629 & .592 & 6.027 & .240 & .188 & .500 & .500 & .410 \\
No. & 612 & 612 & 612 & 612 & 612 & 612 & 612 & 612 & 612 & 612 & 612 \\
\hline R: stockholders return percentage, CF: operational cash flow, EAR:earning before tax \& interest; BETA: systematic risk; SIZE: company size; MTB: market value/book value; ETP:earning per
\end{tabular}

Table 5

Pearson correlation for variables

\begin{tabular}{cccccccccc}
\hline variables & CF & BETA & SIZE & MTB & ETP & LEV & DOMINATED & MACP & INTANG \\
\hline CF & 1 & -.016 & .456 & -.024 & .098 & -.086 & .065 & .067 & .061 \\
BETA & -.016 & 1 & -.039 & -.019 & -.024 & -.054 & .087 & .007 & -.023 \\
SIZE & .456 & -.039 & 1 & -.006 & .097 & .067 & .112 & .083 & -.088 \\
MTB & -.024 & -.019 & -.006 & 1 & -.005 & .114 & .038 & .0817 & -.029 \\
ETP & .098 & -.024 & .097 & -.005 & 1 & -.348 & .007 & .040 & .016 \\
LEV & -.086 & -.054 & .067 & .114 & -.348 & 1 & .061 & .057 & -.018 \\
DOMINATED & .065 & -.087 & .112 & .038 & .007 & .061 & 1 & .051 & .004 \\
MACP & .067 & .007 & .083 & .081 & .040 & .057 & .051 & 1 & -.203 \\
INTANG & .061 & -.023 & -.088 & -.029 & .016 & -.018 & .004 & -.203 & 1 \\
\hline
\end{tabular}

As seen in Table 5, there is not any significant correlation between independent variables and they can be put together in statistical model. The results of testing $\mathrm{H}_{1}$, using panel data with fixed effects are shown in Table 6.

Table 6

The results of analysis for $\mathrm{H}_{1}\left(R_{i t}=\alpha_{0}+\beta_{1} x E A R_{\mathrm{it}}+\beta_{2} x \mathrm{CF}_{\mathrm{it}}+\varepsilon_{0}\right)$

\begin{tabular}{llll}
\hline variables & Coefficient & Statistics & sig \\
\hline constant & 84.7739 & 14.9720 & 0.0000 \\
earning before tax and interests & 0.05583 & 4.8844 & 0.0000 \\
operational cash flow & -0.01694 & -0.8413 & 0.4016 \\
\hline Determination coefficient $=61.37 \%$ modified determination coefficient $=53.02 \%$ Durbin-Watson $=1.74 \mathrm{~F}$ statistics $=7.3539$ Sig. $=0.000$
\end{tabular}


As seen in Table 6, 61.37\% of changes of stock return are explained by two independent variables of earning before tax and interests and operational cash flows. Modified determination coefficient is $53.2 \%$. The effect of earning before tax and interests on stock return is 0.558 , positive, and significant. However, operational cash flow's effect on stock return is insignificant. The value of Durbin-Watson is 1.74. It shows that error components in this model do not have any significant correlation with each other and act independently. Thus, there is no self-correlation between error components of observations. Thus, calculated F statistics' value in measured regression model is 7.353. Thus, at 0.000 level, regression is significant and $\mathrm{H}_{0}$ is rejected.

$\mathrm{H}_{2}$. Increasing information asymmetry, accruals explain stock return of the companies better than operational cash flows.

a. At this state, information asymmetry is measured using dummy variable of MACP. After model estimation, coefficients of earnings before tax and interest and operational cash flow are compared. The results of testing $\mathrm{H} 2$ are shown in Table 7.

\section{Table 7}

Results of $\mathrm{H}_{2}$ analysis

\begin{tabular}{lccc}
$R_{i t}=\alpha_{0}+\beta_{1} x E A R_{\mathrm{it}}+\beta_{2} x \mathrm{CF}_{\mathrm{it}}+\lambda_{1} x \mathrm{BETA}_{\mathrm{it}}+\lambda_{2} x \mathrm{SIZE}_{\mathrm{it}}+\lambda_{3} x \mathrm{MTB}_{\mathrm{it}}+\lambda_{4} x \mathrm{ETP}_{\mathrm{it}}+\lambda_{5} x \mathrm{LEV}_{\mathrm{it}}+\lambda_{6} \mathrm{dummy} \mathrm{MACP}+\varepsilon_{0}$ & sig \\
\hline Variables & coefficients & statistics & 0.9488 \\
\hline Intercept & 28.4702 & 0.0643 & 0.0000 \\
Earnings before tax and interest & 0.05213 & 4.5114 & 0.9930 \\
Operational cash flow & -0.002630 & -0.0087 & 0.4643 \\
Systematic risk & -1.6062 & -0.7324 & 0.9221 \\
Company size & 3.7163 & 0.09784 & 0.0521 \\
Market value/stock holder equity & 1.2752 & 1.9474 & 0.0000 \\
Earnings per share /stock market price & 140.7555 & 7.9132 & 0.8808 \\
Total debt/total assets of the company & -5.1340 & -0.1500 & 0.0662 \\
MACP & -15.0367 & -1.8412 & 0.000 \\
\hline
\end{tabular}

Determination coefficient $=61.09 \%$ modified determination coefficient $=68.46 \%$ Durbin-Watson $=1.87 \mathrm{~F}$ statistics $=9.2895$ Sig. $=0.000$

As seen in Table 7, 68.46\% of stock returns' changes in companies is explained by independent variables. The value of modified determination coefficient is 61.09. The effect of independent variable of earnings before tax and interest on stock return is 0.052 , significant and positive. The effect of market value/ book value of stockholders' equity on stock return is equal to 1.275 , which is positive and significant at 5\% significance level. The effect of earning per share to stock market price of the companies is 140.755 , positive, and significant. Other independent variables have insignificant effect on stock return of the companies Durbin-Watson statistics has a value of 1.87, implying that error components of this model have insignificant correlation with an independent behavior from each other. In other words, there is no self-correlation between error components. Calculated $\mathrm{F}$ statistics in regression model is 9.289 that regarding significance level of 0.000 , it is observed that the regression is significant and $\mathrm{H}_{0}$ is rejected.

b. In that case, information asymmetry is measured using dummy variable of INTANG. Estimating the model, the coefficients of earning before tax and interest and operational cash flow are compared. The results of $\mathrm{H} 2$ analysis are shown in Table 8.

As seen in Table 8, 68.24\% of the changes in stock return of the companies are explained by independent variable in the above model. The value of modified determination coefficient is $60.28 \%$. The effect of earnings before tax and interest on stock return of the companies is 0.0513 , which is positive, and significant. The effect of the ratio of earning per share to stock market value is 138.850 , positive, and significant. Other independent variables don't have significant effect on stock return of the companies. 
Table 8

The results of testing the second hypothesis

\begin{tabular}{lccc}
$R_{i t}=\alpha_{0}+\beta_{1} x E A R_{\text {it }}+\beta_{2} x \mathrm{CF}_{\text {it }}+\lambda_{1} x \mathrm{BETA}_{\mathrm{it}}+\lambda_{2} x \mathrm{SIZE}_{\mathrm{it}}+\lambda_{3} x \mathrm{MTB}_{\mathrm{it}}+\lambda_{4} x \mathrm{ETP}_{\mathrm{it}}+\lambda_{5} x \mathrm{LEV}_{\mathrm{it}}+\lambda_{6}{\mathrm{dummy} \mathrm{INTANG}+\mathrm{e}_{0}}$ & coefficients & statistics & sig \\
\hline Variables & 104.9595 & 0.2370 & 0.8127 \\
\hline Intercept & 0.05138 & 4.4124 & 0.0000 \\
Earnings before tax and interest & 0.00107 & 0.0130 & 0.9896 \\
Operational cash flow & -1.4837 & -0.6745 & 0.5003 \\
Systematic risk & -3.2296 & -0.0851 & 0.9322 \\
Company size & 1.2077 & 1.8408 & 0.0663 \\
Market value/stock holder equity & 138.8507 & 7.7774 & 0.0000 \\
Earnings per share /stock market price & -8.4030 & -0.2450 & 0.8066 \\
Total debt/total assets of the company & -0.1187 & -0.0153 & 0.9878 \\
INTANG &
\end{tabular}

Durbin-Watson value of 1.83 reveals that error components of this model have insignificant correlation together with an independent behavior from each other. In other words, there is no selfcorrelation between error components. Calculated F statistics in regression model is 9. 195. Regarding significance level of 0.000 , it is observed that the regression is significant and $\mathrm{HO}$ is rejected.

c. In this state, information asymmetry is measured using dummy variable of DOMINATED. Estimating model, the coefficients of earning before tax and interest and operational cash flow are compared. The results of $\mathrm{H} 3$ analysis are shown in Table 9.

\section{Table 9}

The results of testing the thirds hypothesis

\begin{tabular}{lccc}
$R_{i t}=\alpha_{0}+\beta_{1} x E A R_{\mathrm{it}}+\beta_{2} x \mathrm{CF}_{\mathrm{it}}+\lambda_{1} x \mathrm{BETA}_{\mathrm{it}}+\lambda_{2} x \mathrm{SIZE}_{\mathrm{it}}+\lambda_{3} x \mathrm{MTB}_{\mathrm{it}}+\lambda_{4} x \mathrm{ETP}_{\mathrm{it}}+\lambda_{5} x \mathrm{LEV}_{\mathrm{it}}+\lambda_{6} \mathrm{dummy} \mathrm{DOMINATED}_{\mathrm{it}}+\mathrm{e}_{0}$ \\
\hline Intercept & Coefficients & Statistics & Sig. \\
\hline Earnings before tax and interest & 126.4134 & 0.2838 & 0.7766 \\
Operational cash flow & 0.05138 & 4.4354 & 0.0000 \\
Systematic risk & -0.001844 & -0.0061 & 0.9951 \\
Company size & -1.4200 & -0.6441 & 0.5198 \\
Market value/stock holder equity & -4.5982 & -0.1208 & 0.9039 \\
Earnings per share /stock market price & 1.2132 & 1.8491 & 0.0650 \\
Total debt/total assets of the company & 139.2538 & 7.8042 & 0.0000 \\
Intercept & -8.4808 & -0.2474 & 0.8047 \\
DOMINATED & -7.0416 & -0.4173 & 0.6766 \\
\hline Determination coefficient $=68.25 \%$ modified determination coefficient $=60.83 \%$ Durbin-Watson $=1.91 \mathrm{~F}$ statistics $=9.2007$ Sig. $=0.000$
\end{tabular}

As seen in Table 9, 68.25\% of stock return's changes in the companies are explained by independent variables of the model. The value of modified determination coefficient regarding sample size is $60.83 \%$. The effect of earning before tax and interest on stock return of the companies is equal to 0.0513 , which is positive, and significant. The effect of the ratio of earning per share to stock return of the companies is 139.253, positive, and significant. Other independent variables don't have significant effect on stock return of the companies. Durbin-Watson statistics has a value of 1.91, implying that error components of this model have insignificant correlation with an independent behavior from each other. In other words, there is no self-correlation between error components. Calculated F statistics in regression model is 9.2007 that regarding significance level of 0.000 it is observed that the regression is significant and $\mathrm{H}_{0}$ is rejected.

\section{Conclusion}

The results of the study have shown that earning before tax and interest had positive and significant correlation with stock return of the companies. While, this correlation is insignificant between operational cash flows and stock return of the companies. According to the findings, increasing 
information asymmetry, earning before tax and interest had positive and significant correlation with stock return of the companies. However, the effect of cash flows on stock return was insignificant. In other words, earning before tax and interest had higher information content compared with operational cash flows. The results are consistent with findings of Gombola and Ketz (1983), Easton et al. (1992), Haw et al. (2001) who confirmed that accounting earning had higher information content than cash flows. The study of Rapp (2010 shows that accounting earning contained higher information content than cash flows. Increasing information asymmetry, the measure of cash flow had a better performance in explaining capital market. This study also proved that earning before tax and interest has higher information content than cash flow.

\section{References}

Bartov, E., Goldberg, S. R., \& Kim, M. S. (2001). The Valuation-relevance of Earnings and Cash Flows: an International Perspective. Journal of International Financial Management \& Accounting, 12(2), 103-132.

Bowen, R. M., Burgstahler, D., \& Daley, L. A. (1987). The incremental information content of accrual versus cash flows. Accounting Review, 62(4), 723-747.

Charitou, A., Clubb, C., \& Andreou, A. (2000). The value relevance of earnings and cash flows: empirical evidence for Japan. Journal of International Financial Management \& Accounting, 11(1), 1-22.

Chan, K., Chan, L. K., Jegadeesh, N., \& Lakonishok, J. (2006). Earnings Quality and Stock Returns*. The Journal of Business, 79(3), 1041-1082.

Dechow, P. M. (1994). Accounting earnings and cash flows as measures of firm performance: The role of accounting accruals. Journal of accounting and economics, 18(1), 3-42.

Easton, P. D., Harris, T. S., \& Ohlson, J. A. (1992). Aggregate accounting earnings can explain most of security returns: The case of long return intervals. Journal of Accounting and Economics, 15(2), 119-142.

Gombola, M. J., \& Ketz, J. E. (1983). A caveat on measuring cash flow and solvency. Financial Analysts Journal, 39(5), 66-72.

Haw, I. M., Qi, D., \& Wu, W. (2001). The nature of information in accruals and cash flows in an emerging capital market: The case of China. The International Journal of Accounting, 36(4), 391406.

Hodgson, A., \& Stevenson-Clarke, P. (2000). Earnings, cashflows and returns: Functional relations and the impact of firm size. Accounting \& Finance, 40(1), 51-74.

Rayburn, J. (1986). The association of operating cash flow and accruals with security returns. Journal of Accounting Research, 24, 112-133.

Subramanyam, K. R., \& Venkatachalam, M. (2007). Earnings, cash flows, and ex post intrinsic value of equity. The Accounting Review, 82(2), 457-481.

Rapp, M. (2010). Information asymmetries and the value-relevance of cash flow and accounting figures-empirical analysis and implications for managerial accounting.

Wilson, G. P. (1987). 1986 Competitive Manuscript Award: The Incremental Information Content of the Accrual and Funds Components of Earnings after Controlling for Earnings. Accounting Review, 62, 293-322. 